\title{
Morphological and ecological investigations on sympatric Lipophrys species (Blenniidae, Pisces)
}

\author{
C. D. Zander \\ Zoologisches Institut und Zoologisches Museum; \\ Universität, Martin-Luther-King-Platz, D-2000 Hamburg, Federal Republic of Germany
}

\begin{abstract}
The three syntopic blenniids Lipophrys canevai, L. adriaticus, and $L$. dalmatinus were investigated off Katarina Island near Rovinj, Yugoslavia, in regard to their habitats and food organisms. The shallow, sheltered rocky sea shore turned out to be the characteristic habitat for $L$. dalmatinus and $L$. adriaticus, whereas $L$. canevai also inhabits surf-exposed biotopes. The overlap of the microhabitats was below $50 \%$. Algae are the main food of all three species with respect to biomass, but harpacticoids dominated in $L$. adriaticus and especially $L$. dalmatinus when considering abundance of food organisms. Overlap of trophic niches was high $(80 \%)$ between $L$. canevai and $L$. adriaticus but lower $(<45 \%)$ between $L$. dalmatinus and the other two species. Morphological studies considered external morphology, pigmentation, and anatomy of eyes, including the closely related, cave-dwelling $L$. nigriceps. This species reveals special adaptations to life in dimly lit biotopes: reduction of the basic melanophore pigmentation, development of clinging organs, and enlargement of eyes and lenses combined with an effective ratio of retinal elements and modes of accommodation. It is concluded that the four species are members of one "Lebensorttyp" (Riedl, 1966) of which $L$. nigriceps has superimposed the basic characteristics with specializations to a greater and the other three species to a lesser degree.
\end{abstract}

\section{INTRODUCTION}

Blenniid fish of the genus Lipophrys are widely distributed in the Mediterranean Sea: L. trigloides (L.), L. canevai (Steindachner \& Kolombatovic), L. dalmatinus (Steindachner \& Kolombatovic), L. adriaticus (Vinciguerra), and L. nigriceps (Vinciguerra). Whereas $L$, trigloides inhabits steep rocks in the surf area (Zander, 1972b), and $L$. nigriceps sea caves or other dimly lit biotopes (Abel, 1959; Zander \& Jelinek, 1976; Zander \& Heymer, 1977), the other three species are found in the shallow, algae-covered littoral zone. L. adriaticus and dalmatinus have not been found yet throughout the entire Mediterranean Sea; the former does not seem to occur in the Gulf of Lion or the North African coast (Zander, 1972b).

Hence, the question arises concerning the degree to which $L$. canevai, L. adriaticus and $L$. dalmatinus are adapted to different ecological niches in the same biotope. The present investigations relate morphological adaptations of Lipophrys species to their respective habitats; $L$. nigriceps, whose habitat and prey were investigated formerly (Zander \& Jelinek, 1976; Zander \& Heymer, 1977), is included and mention is made of $L$. velifer of Senegal. Though the habitats and food of $L$. canevai and $L$. dalmatinus have been described from other regions of the Mediterranean Sea (Zander, 1972b; Zander 


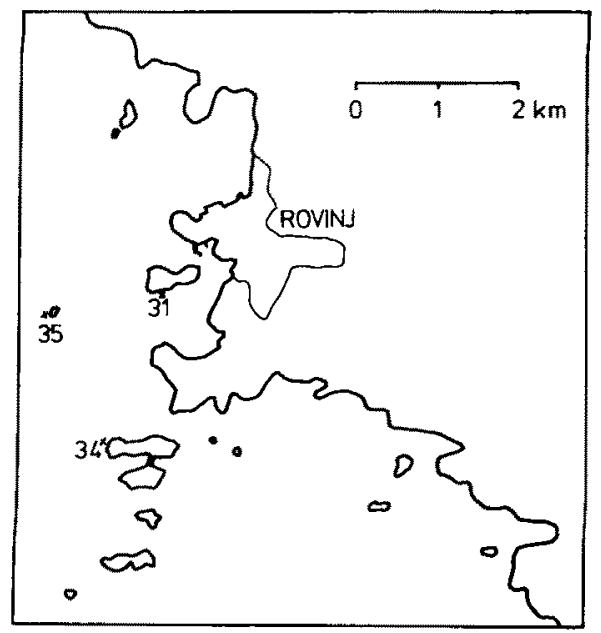

Fig. 1. Sites of investigation off Rovinj, Yugoslavia (Adriatic Sea). 31: Katarina Island; 34: Red Island; 35: Banjole Island

\& Bartsch, 1972), these studies did not consider syntopy and possible interspecific competition. On the Yugoslavian Adriatic coast we found the necessary conditions for such investigations: All five Mediterranean Lipophrys species could be observed and collécted at different islands off Rovinj in the years 1973 and 1975.

\section{MATERIAL AND METHODS}

The main investigation site was the southern coast of Katarina Island, where a syntopy of $L$. canevai, $L$. adriaticus and $L$. dalmatinus was most evident (Fig. 1, No. 31 ). For comparable reasons, $L$. canevai individuals from Red Island ( =Crveni Otok, Fig. 1 , No. 34) also were studied. The fish were caught with hand nets during skin-diving and fixed in $4 \%$ formalin within an hour. After measuring and weighing the guts were removed and the contents taxonomically assessed and counted. Algae were counted by estimating bites according to the width of the mouth of the respective fish. Contrary to the other components, the dry weight of algae was evaluated directly from material ingested by the fish.

For estimating the potentially available food a phytal sample of an area of $50 \mathrm{~cm}^{2}$ was scratched from the substrate (Fig. 2). It was taken up in a plastic bag which was closed under water, yielding an almost quantitative phytal sample with its fauna. Algae and fauna were approximately identified, counted and dry weights were determined. The respective mean weights were used for estimating the biomass taken up by the fish.

Fullness index (Hureau, 1969), feeding selectivity (Berg, 1979), and niche overlap (Colwell \& Futuyma, 1971) were evaluated.

In addition to specimens from the Rovinj area, L. dalmatinus from France (Banyulssur-Mer and Meze) and Spain (Tarragona) as well as $L$. velifer from Senegal (Isle de Gorée) were investigated for morphological studies. The heads of the fish were prepared for histological treatments, cut in $10-\mu \mathrm{m}$ serial sections and stained with Pasini. The 


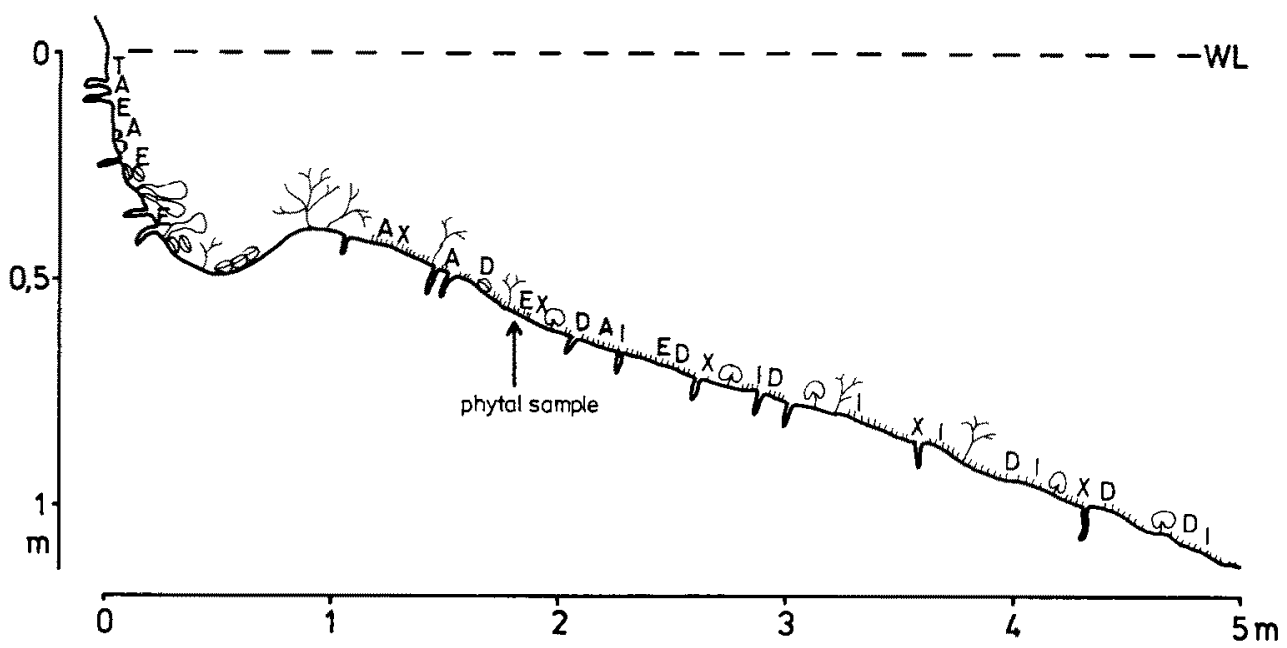

Fig. 2. Transverse section of the investigation site at Katarina Island: (A) Lipophrys adriaticus, (D) $L$. dalmatinus, (E) L. canevai, (I) Parablennius incognitus, (T) L. trigloides, (X) P. sphynx

measurements and counts of the retinal elements were performed using an eye-piece micrometer.

\section{ECOLOGY OF THE LIPOPHRYS SPECIES}

\section{Habitat}

The investigation site on the southern coast of Katarina (Fig. 1, No 31) was exposed to full sunlight. A steep slope changed to an almost plane rocky terrace at $0.5 \mathrm{~m}$ below water level (Fig. 2). The steep slope was uncovered down to $0.2 \mathrm{~m}$ below water level, then overgrown by balanoids and Mytilus and from $0.3 \mathrm{~m}$ by algae, especially Ulva. The rock terrace only occasionally exhibited larger algae such as Cystoseira or Padina but was totally covered by a delicate Cladophora carpet. Everywhere holes of piddocks of various sizes were found, which are used by Lipophrys and other blenniids as spawning places.

Table 1. Distribution of 3 Lipophrys species to different microhabitats of the investigated biotope at Katarina Island

\begin{tabular}{|lrrc|}
\hline Incline and depth & L. canevai & L. adriaticus & L. dalmatinus \\
\hline Steep wall $0-25 \mathrm{~cm}$ & $3=11.5 \%$ & $13=56.5 \%$ & 0 \\
Steep wall $25-50 \mathrm{~cm}$ & $10=38.5 \%$ & $3=13.0 \%$ & 0 \\
Rock terrace $<50 \mathrm{~cm}$ & $5=19.2 \%$ & $5=21.7 \%$ & $4=28.6 \%$ \\
Rock terrace $50-100 \mathrm{~cm}$ & $8=30.8 \%$ & $2=8.7 \%$ & $4=28.6 \%$ \\
Rock terrace $>100 \mathrm{~cm}$ & 0 & 0 & $6=42.8 \%$ \\
\hline n & 26 & 24 & 14 \\
Density in the main microhabitat $\left(\mathrm{m}^{2}\right)$ & 4 & 8 & 2 \\
\hline
\end{tabular}


Table 2. Microhabitat overlap of 3 Lipophrys species; ranges may stretch from 0 (no overlap) to 1 (total overlap)

\begin{tabular}{|ccc|}
\hline Species & L. adriaticus & L. dalmatinus \\
\hline L. canevai & 0.412 & 0.478 \\
L. adriaticus & - & 0.304 \\
\hline
\end{tabular}

Table 3. Flight distance and main flight direction of 3 Lipophrys species

\begin{tabular}{|clll|}
\hline Species & L. canevai & L. adriaticus & L. dalmatinus \\
\hline Flight distance & middle & very low & middle \\
Flight direction & upwards & upwards & all directions \\
\hline
\end{tabular}

Whereas only $L$, adriaticus and $L$. canevai were observed at the steep wall, all 3 species inhabited the rock terrace, albeit at different frequencies (Table 1). Using these results, an evaluation of the overlaps in microhabitats demonstrates that in every case the values are below $50 \%$ and are lowest between $L$. adriaticus and $L$. dalmatinus (Table 2).

The periods of activity turned out to be dependent on full sunshine in $L$. adriaticus and to a lesser degree in $L$. dalmatinus, whereas $L$. canevai was observed at shadowy sites as well. These results confirm former investigations (Zander, 1972b). During rainy weather all $L$. adriaticus and most $L$. dalmatinus individuals stayed in their residence holes. Distance and direction of escape are also different in the three species (Table 3).

\section{Food}

Potentially available food. The analysis of the phytal samples taken at $0.6 \mathrm{~m}$ below water level on the rock terrace (Fig. 2) showed a broad spectrum of potential food organisms. The investigated area of $50 \mathrm{~cm}^{2}$ contained a total biomass of $1886 \mathrm{mg} \mathrm{W}$ which consisted mainly of algae (93\%; Fig. 3). Among faunal elements, bivalves (71 \%) dominated over polychaetes $(10 \%)$ and gammarids $(6 \%)$, which were followed by meiofauna organisms such as harpacticoids (4\%) or foraminifers (3\%) (Fig. 3). In regard to abundance (total number of individuals $=4150$ ), the meiofauna dominated by far, consisting of harpacticoids $(40 \%)$, nematodes $(16 \%)$ and foraminifers $(12 \%)$. The most numerous macrofauna were bivalves $(13 \%)$ and polychaetes $(10 \%)$. The degree to which this food source is used by the Lipophrys species will be analysed in the next section.

Food uptake. The total lengths and wet weights of the examined fish are shown in Figure 4. L. canevai is the largest and heaviest species, and $L$. dalmatinus, the smallest known blenniin species, is the lightest.

The fullness index, the relative quantity of ingested food, is very high in $L$. canevai (6.4), but lower in L. adriaticus (2.0) and in $L$. dalmatinus (2.7) (Fig. 4). These values correspond to the mean biomass of the food ingested by one fish (Table 4). 


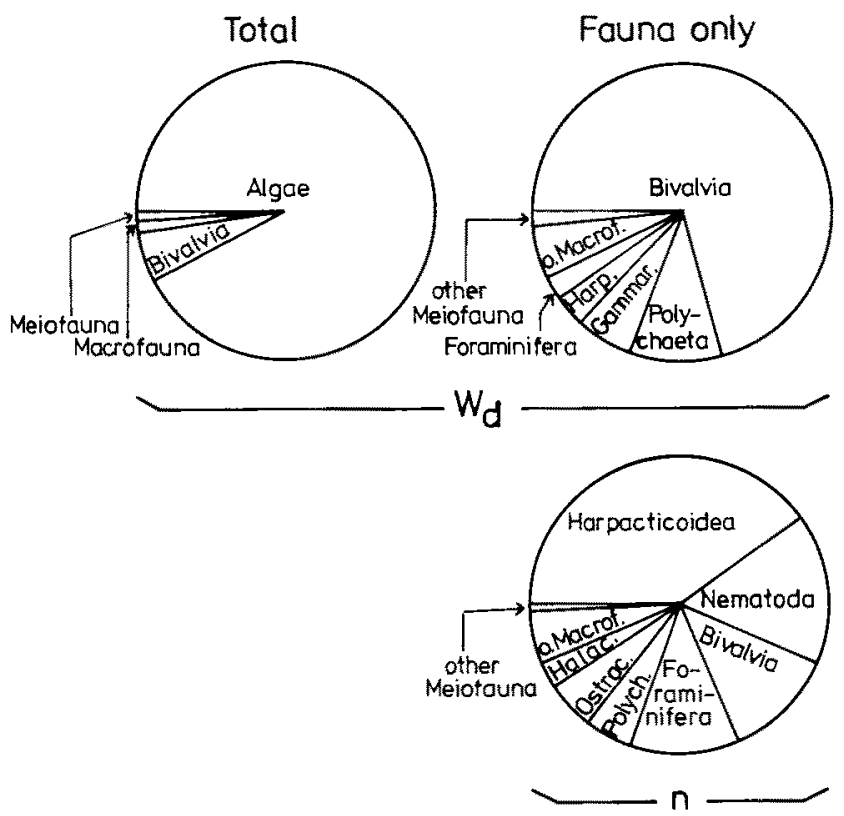

Fig. 3. Potential available food from a phytal sample. Above: dry weight, below: numbers; left: fauna and flora, right: fauna only

C

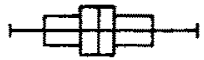

A

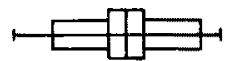

D
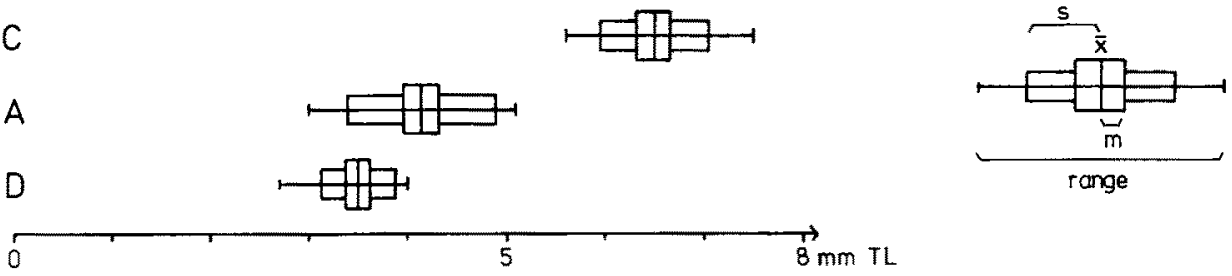

$\mathrm{C}$
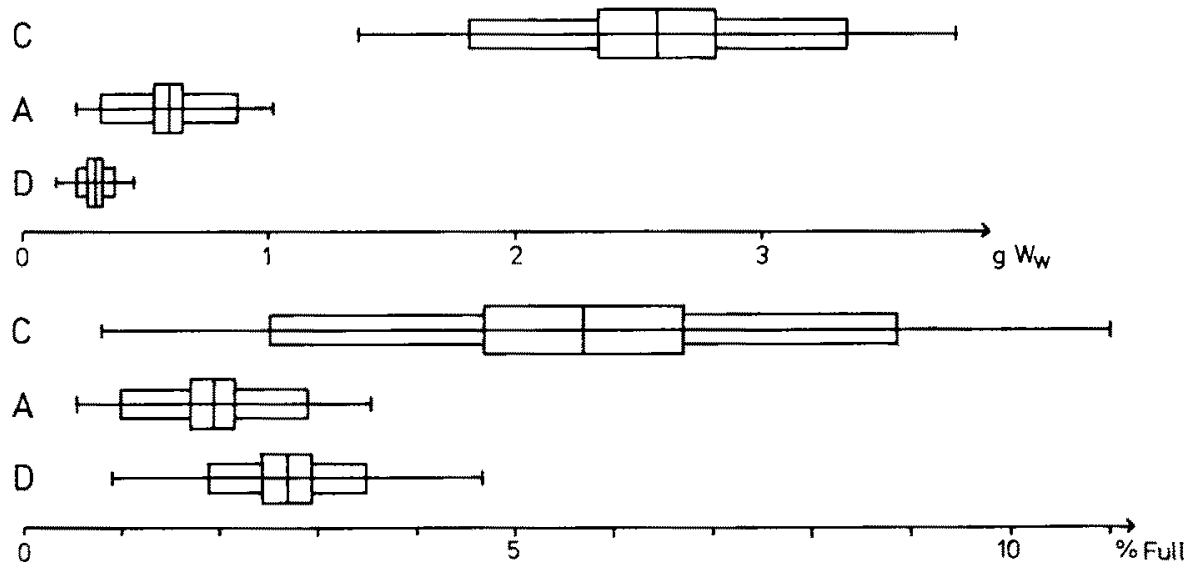

Fig. 4. Miller graphs of total lengths (above), wet weights (middle) and fullness indexes (below) of three Lipophrys species. (A) L. adriaticus, (C) L. canevai, (D) L. dalmatinus; m: mean error, $\mathrm{s}$ : standard deviation, $\mathrm{x}$ : mean value 
Table 4. Mean values of food ingested by 3 Lipophrys species

\begin{tabular}{|lccc|}
\hline \multicolumn{1}{|c}{ Ratios } & L. canevai & L. adriaticus & L. dalmatinus \\
\hline $\mathrm{W}_{\mathrm{w}}$ mg (related to gut content) & 142.8 & 10.8 & 8.1 \\
$\mathrm{~W}_{\mathrm{d}}$ mg (related to potentially available food) & 6.01 & 0.60 & 0.48 \\
$\mathrm{~W}_{\mathrm{w}} / \mathrm{W}_{\mathrm{d}}$ & 23.76 & 18.29 & 16.88 \\
$\mathrm{n}$ & 10 & 18 & 10 \\
\hline
\end{tabular}

The abundance analysis gives a measure for feeding activity of the fish and also shows what components are fed on most frequently (Fig. 5). Whereas harpacticoids dominated in the small $L$. adriaticus and $L$. dalmatinus, $L$. canevai fed primarily on algae. Hence the results of Zander \& Bartsch (1972) can be confirmed in principle. Since the proportion of algae seemed unexpectedly high in $L$. canevai, five specimens from Red Island (Fig. 1, No. 34) were compared in this respect. They preferred algae as well, but not in such large quantities as the Katarina population, and had taken up a high proportion of harpacticoids and cypris larvae along with some macrofauna components (Fig. 5).

The food of L. nigriceps, which is not syntopic with the other three species, had been investigated previously in specimens from the Banjole grotto (Fig. 1, No. 35) (Zander \& Heymer, 1977). They had fed primarily on aufwuchs, which consisted not only of algae but also hydrozoans and balanoids (Fig. 5).

The biomass of food organisms showed that algae were the major component for all three species, accounting for $98 \%$ in $L$. canevai (Fig. 6). The two smaller species replace the algae increasingly by faunal elements, the largest proportion being harpacticoids. $L$.
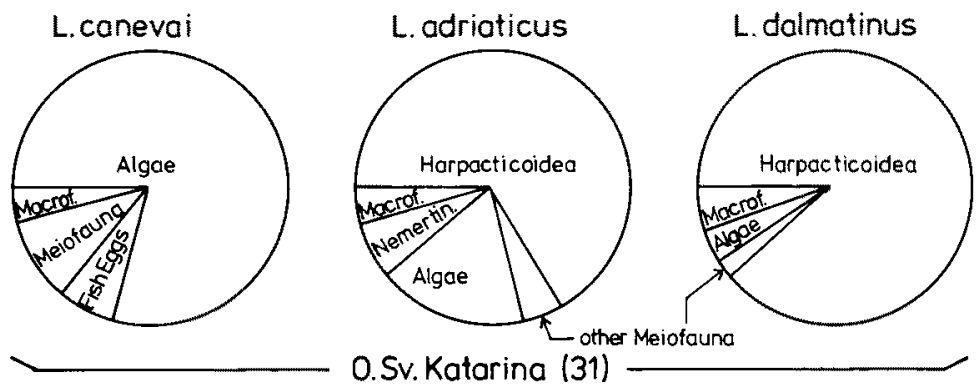

L. nigriceps
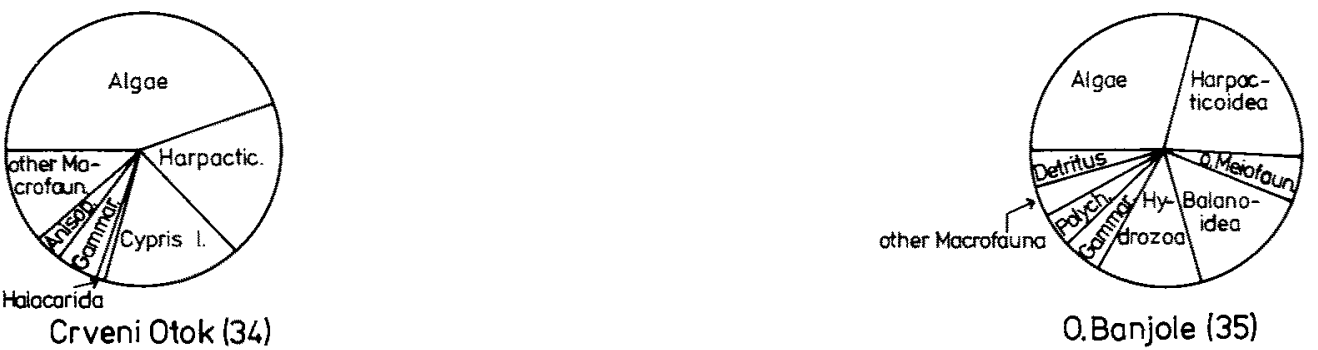

Crveni Otok (34)

O.Banjole (35)

Fig. 5. Abundance analysis (numbers) of gut contents of three Lipophrys species; above: populations of Katarina Island, below: other populations 
dalmatinus had fed on macrofauna such as gammarids and polychaetes in larger quantities (Fig. 6).

A frequency analysis gives information on how regularly particular food organisms are taken up by a fish population, but gives no information about quantities (Berg, 1979; Zander, 1979a). Algae are fed on by all $L$. canevai and $L$. adriaticus (Fig. 7 ), and all $L$. dalmatinus had ingested harpacticoids. $L$. adriaticus frequently fed on harpacticoids, and $L$. dalmatinus on algae and polychaetes (Fig. 7).

The evaluation of feeding selectivity provides evidence of the preferred or avoided food. Since only dry weights but no abundance data were available for the algae from the phytal sample, this parameter was evaluated relative to the biomass of the single

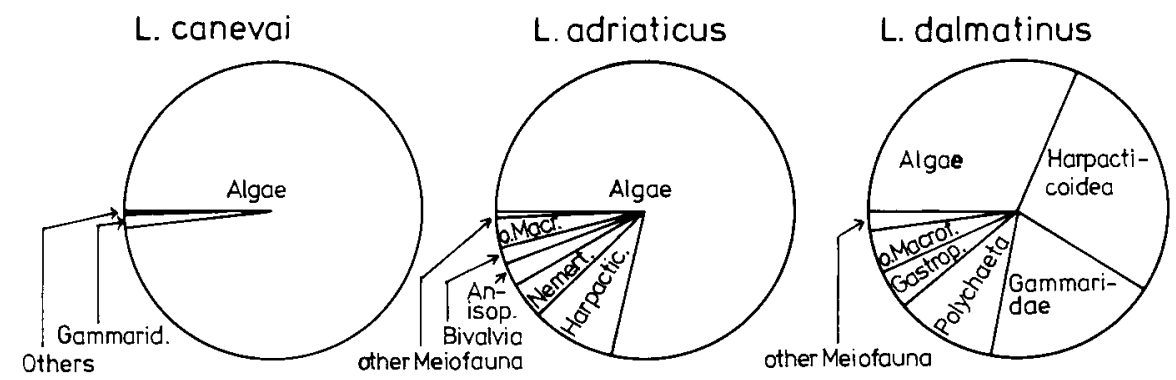

Fig. 6. Biomass analysis (dry weights) of gut contents of three Lipophrys species from Katariıa Island

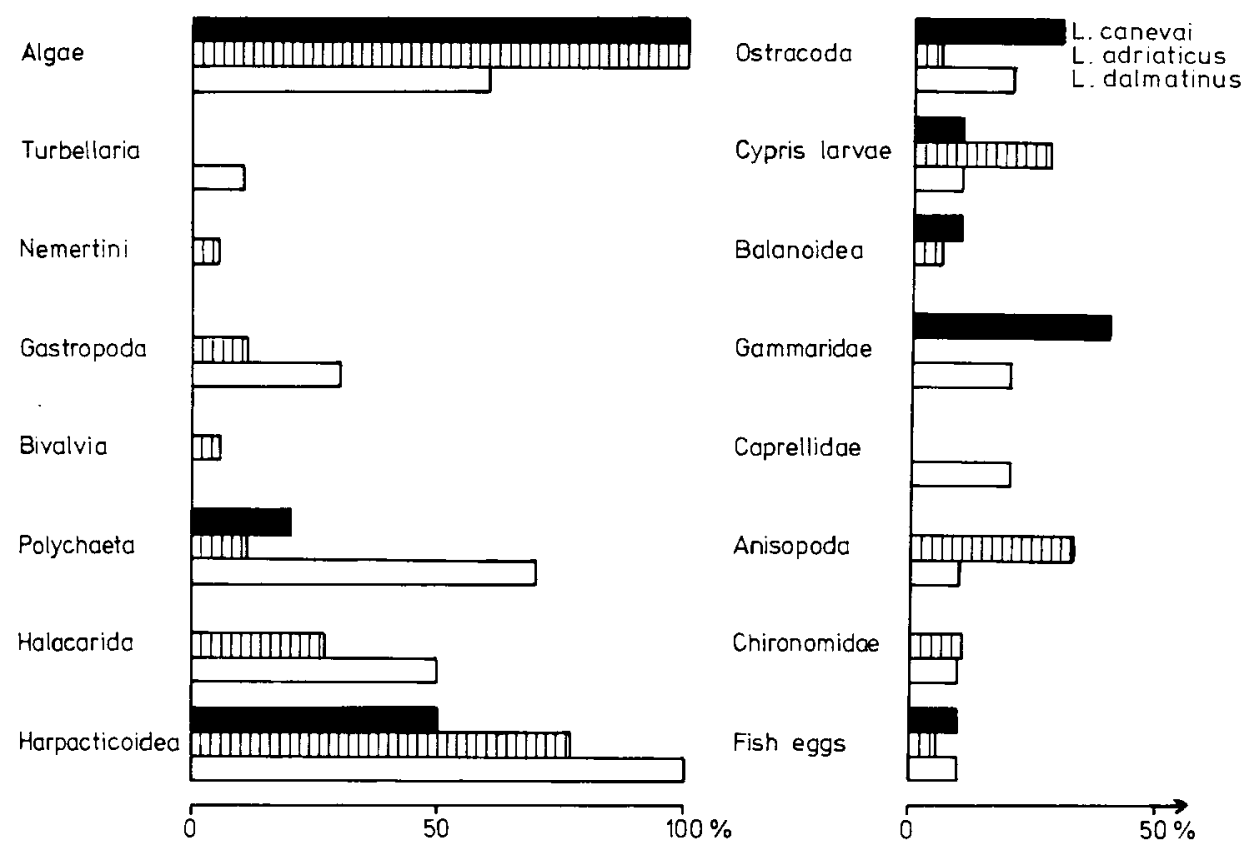

Fig. 7. Frequency analysis (percent occurrence) of gut contents of three Lipophrys species ( $L$. canevai, L. adriaticus, L. dalmatinus) from Katarina Island 
components (Fig. 8). All three species preferred anisopods and fish eggs; the smaller species $L$. adriaticus and $L$. dalmatinus also consumed meiofauna (harpacticoids, halacarids, ostracods) and some macrofaunal elements (gastropods, polychaetes, chironomids). Gammarids, which are preferred by $L$. canevai and $L$. dalmatinus, were avoided by $L$. adriaticus totally. Preferred food of only a single fish species were: algae by $L$. canevai, nemertines and balanoids by $L$. adriaticus, and turbellarians by $L$. dalmatinus (Fig. 8 ).

The different feeding habits of the three Lipophrys species may also be expressed by the specific niche overlap considering the biomass of ingested food (Table 5). Whereas $L$. canevai and $L$. adriaticus show a high degree of overlap (80\%), L. dalmatinus is in less competition with its relatives, feeding on a high percentage of meiofauna (Table 5).

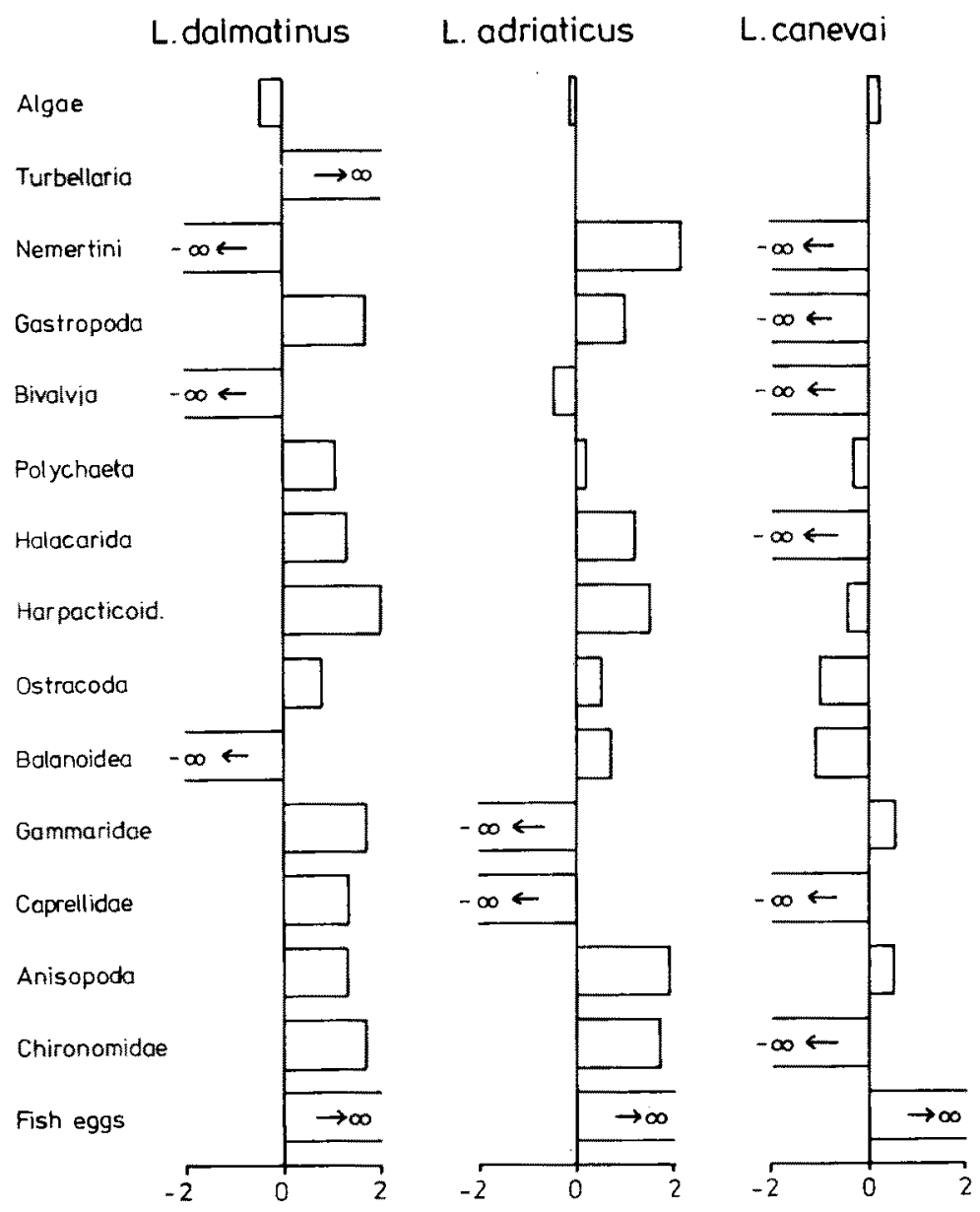

Fig. 8. Feeding selectivity of three Lipophrys species from Katarina Island. O: prey in identical percentages in the gut and in the potentially available food; 0 : prey absent in the phytal sample;

- D: offered food not preyed on by the fish 
Table 5. Food overlap of 3 Lipophrys species; range from 0 (no overlap) to 1 (total overlap)

\begin{tabular}{|ccc|}
\hline Species & L. adriaticus & L. dalmatinus \\
\hline L. canevai & 0.792 & 0.332 \\
L. adriaticus & - & 0.444 \\
\hline
\end{tabular}

\section{MORPHOLOGY}

\section{External morphology}

As the external morphology of $L$, canevai and $L$. dalmatinus has been described previously (Zander, 1972b, 1973), that of $L$. adriaticus and L. nigriceps will be outlined here. These two species also have long and compressed bodies; $L$. nigriceps has a strikingly narrow head and belly (Fig. 9, 10). The lower rays of the pectoral fin end in little hooks, 4 in L. adriaticus and 6 in L. nigriceps - the greatest count in blenniids until

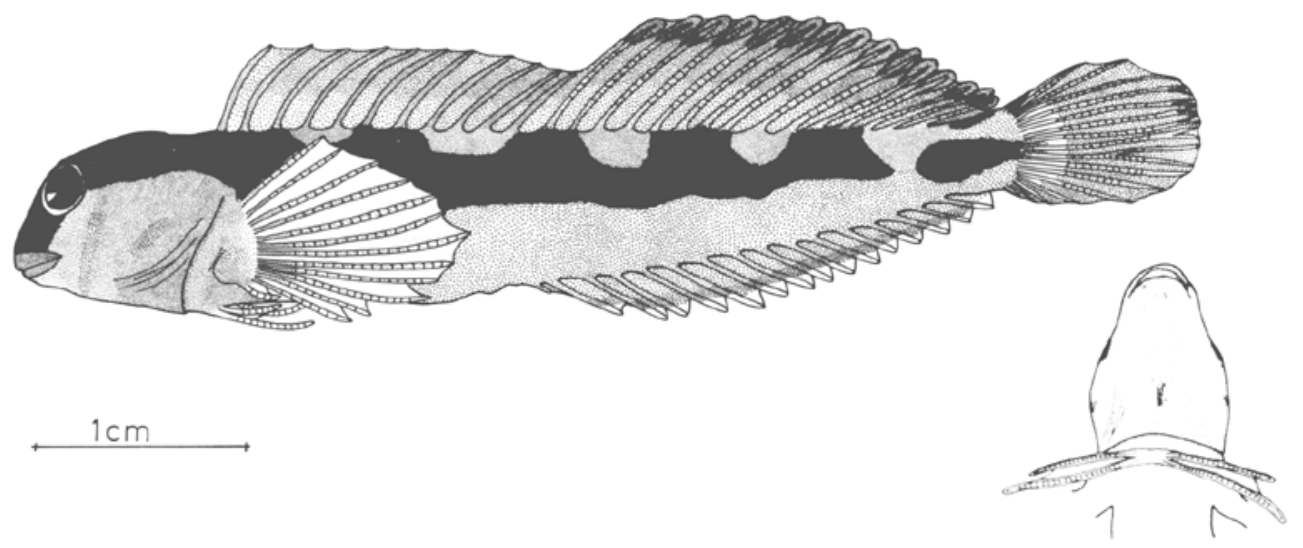

Fig. 9. General aspect and melanophore colouring of Lipophrys adriaticus. Right: Ventral view of head and front body (drawing; A. Dowling)
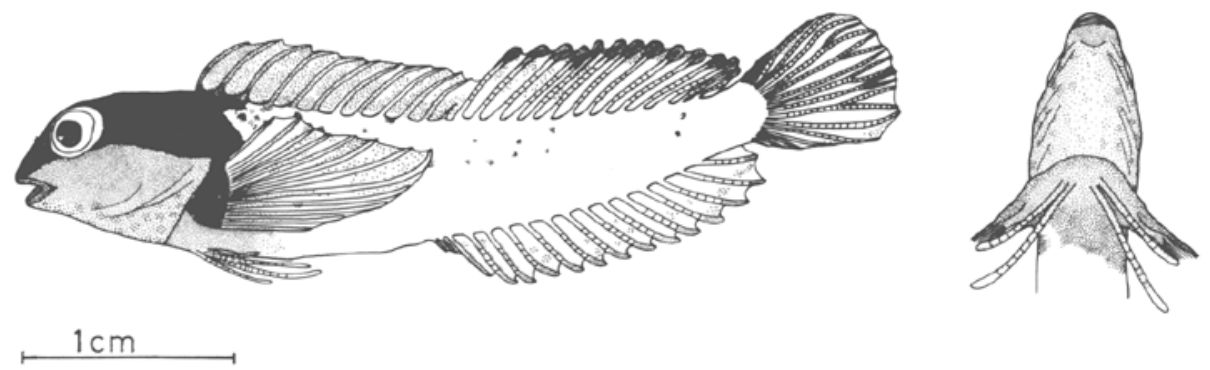

Fig. 10. General aspect and melanophore colouring of Lipophrys nigriceps. Right: Ventral view of head and front body (drawing: A. Dowling) 
now. The two parts of the pelvic fins of $L$. nigriceps are very long and deeply notched, they end obtusely and not acutely as in the other species (Fig. 10). In L. adriaticus the pelvic fins are stronger and not as deeply notched as in L, nigriceps (Fig. 9). The rays of the anal fins of both species end in little hooks. A thin cuticula on the ventral parts of the fins was observed only in $L$. adriaticus.

The lateral line of $L$ adriaticus possesses only a few pores near the head region. This organ is repeatedly interrupted and is without any pores in $L$. nigriceps.

\section{Pigmentation}

The basic colour pattern built up by melanophores and xanthophores and the specific colour pattern consisting of all types of chromatophores are to be distinguished. Species of Lipophrys are known to display an ethological colour change as well as a geographical variability (Zander, 1969, 1972b). During the spawning season the males have a head mask with a black crown and brillantly coloured cheeks (Abel, 1962; Zander, 1975).

The crown of $L$. adriaticus is continued on the back of the whole body, interrupted there by many light spots (Fig, 9). The other parts of the head and body are yellow with some melanophores. L. nigriceps, on the other hand, only has black patterns on the head, the front body and more seldom on the hind body, melanophores of the basic pattern
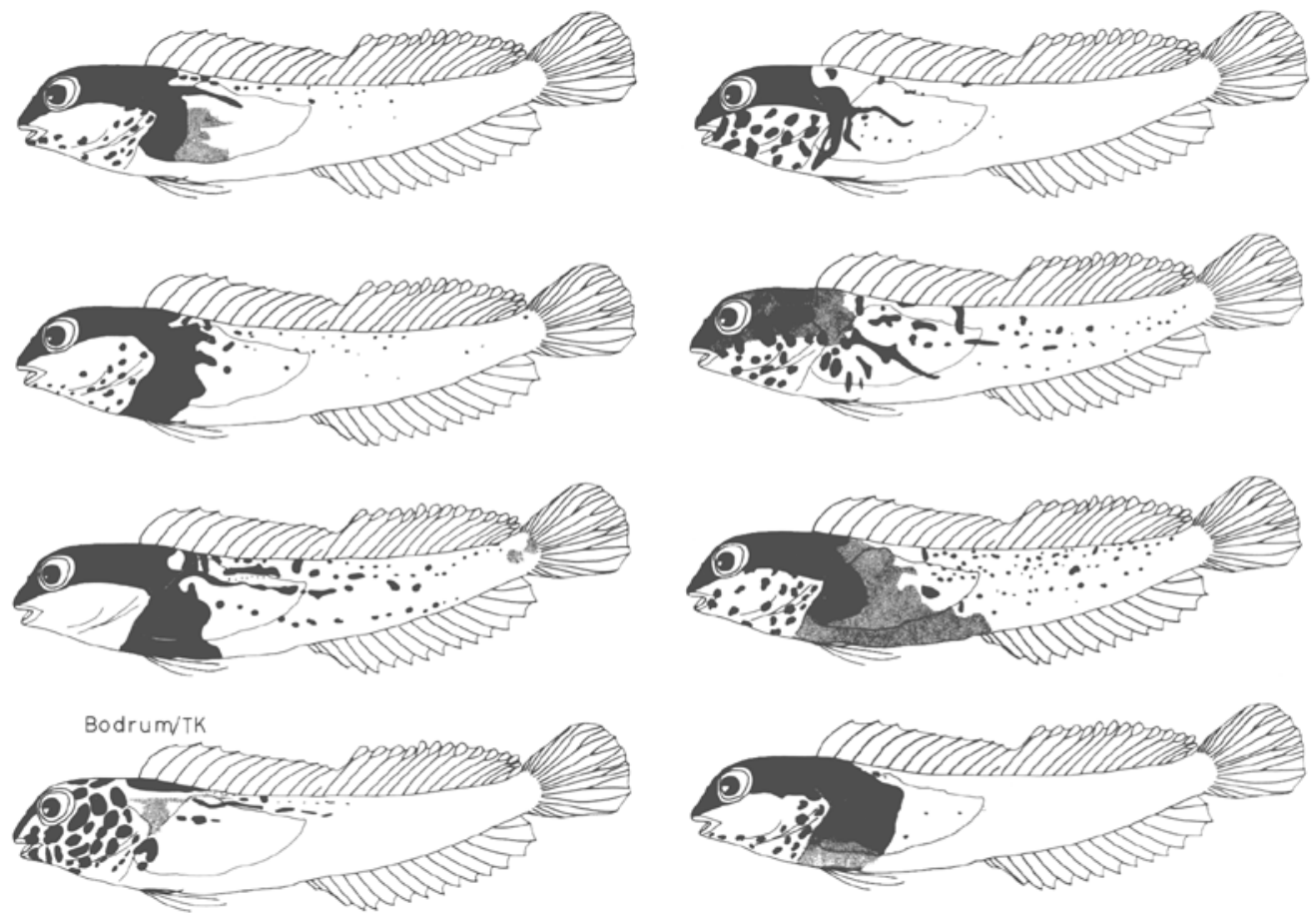

Fig. 11. Variability of melanophore patterns in 7 Lipophrys nigriceps from the Banjole grotto and one from Bodrum, Turkey (drawing: A. Dowling) 
being absent (Figs 10-12). The males' head mask is a very broad black crown which runs over the hind operculum onto the belly. The body pattern consists of black, interrupted lines or spots, often only weakly visible and very variable in each specimen (Fig. 11). The remaining body of L. nigriceps is bright red, whereas the head has yellow cheeks. Non-spawning males and all females have a marbled head instead of the head mask (Fig. 11).

Table 6. Number of melanophores in Lipophrys species from different body regions; area: $0.1 \mathrm{~mm}^{2}$

\begin{tabular}{|lccc|}
\hline Species & $\begin{array}{c}\text { Beginning of } \\
\text { pectoral fin }\end{array}$ & $\begin{array}{c}\text { Beginning of } \\
\text { soft dorsal fin }\end{array}$ & $\begin{array}{c}\text { Caudal } \\
\text { peduncle }\end{array}$ \\
\hline L. nigriceps - red & 0 & 0 & 4 \\
L. nigriceps - brown & 20 & 16 & 19 \\
L. canevai & 24 & 20 & 19 \\
\hline
\end{tabular}

Only one of $45 \mathrm{~L}$. nigriceps individuals caught in the Banjole grotto was brown instead of red and was at first confused with $L$. canevai (Fig. 12). A comparison of melanophore counts along the back of $L$. canevai and $L$, nigriceps is compiled in Table 6 . These results did not yield differences between $L$. canevai and brown $L$. nigriceps, whereas melanophores are almost totally absent in the red ones (Fig. 12).
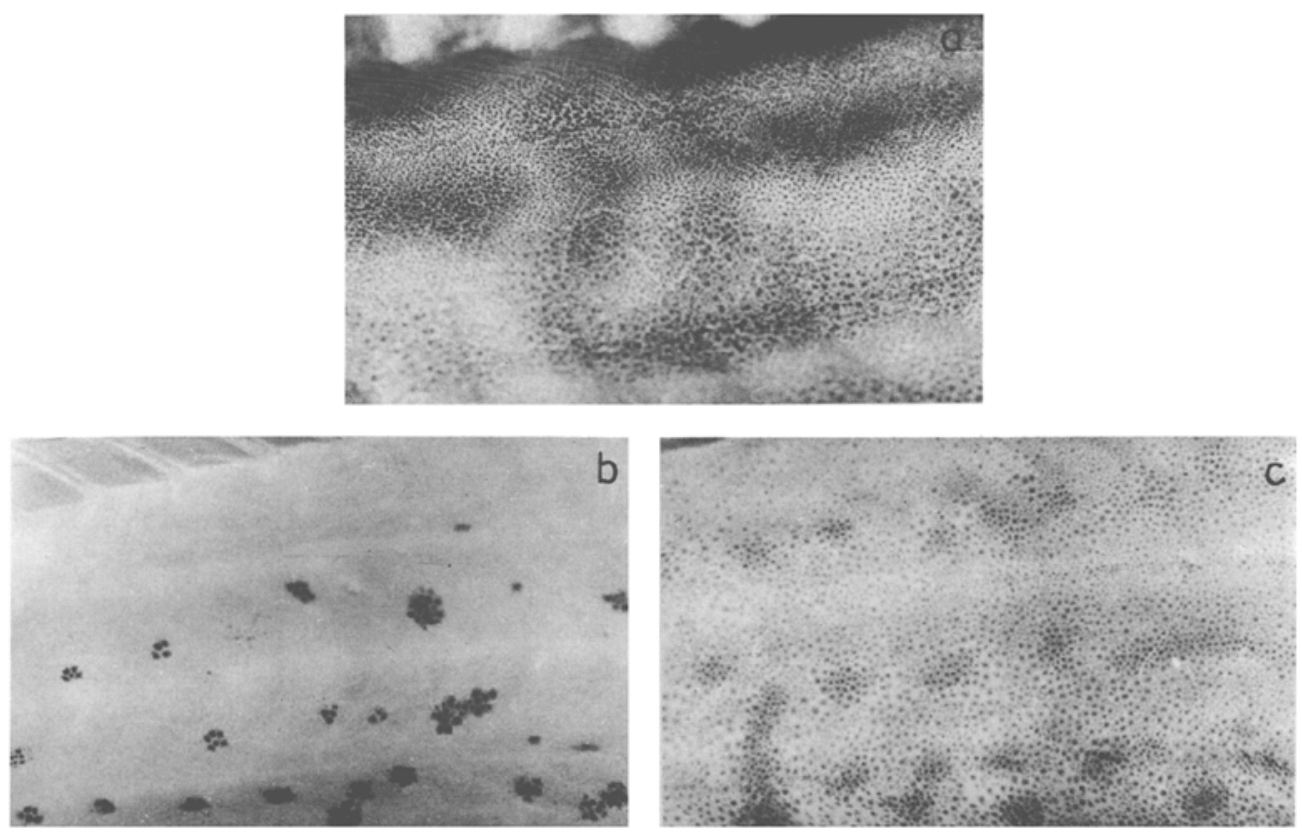

Fig. 12. Photographs of skin below the beginning of soft dorsal fin rays, showing melanophore patterns; (a) Lipophrys canevai, (b) red L. nigriceps, (c) brown L. nigriceps 


\section{Eyes}

For five Lipophrys species an eye index was evaluated by means of the quotient eye diameter: total length (Fig. 13). The lowest values were found in $L$. canevai, somewhat higher ones in $L$. adriaticus, $L$. velifer and $L$. dalmatinus, and very high ones in $L$. nigriceps. The regression of indices to the total length was calculated in order to test the possibility of an allometric growth of the eye (Fig. 13). Whereas the eyes of $L$. dalmatinus and maybe $L$. canevai grow almost isometrically, larger specimens of the other three species show relatively lower eye diameters than small specimens. This is demonstrated very clearly in the graph for $L$. adriaticus (Fig. 13). The eyes of $L$. nigriceps are also characterized by their prominent size with respect to this regression.
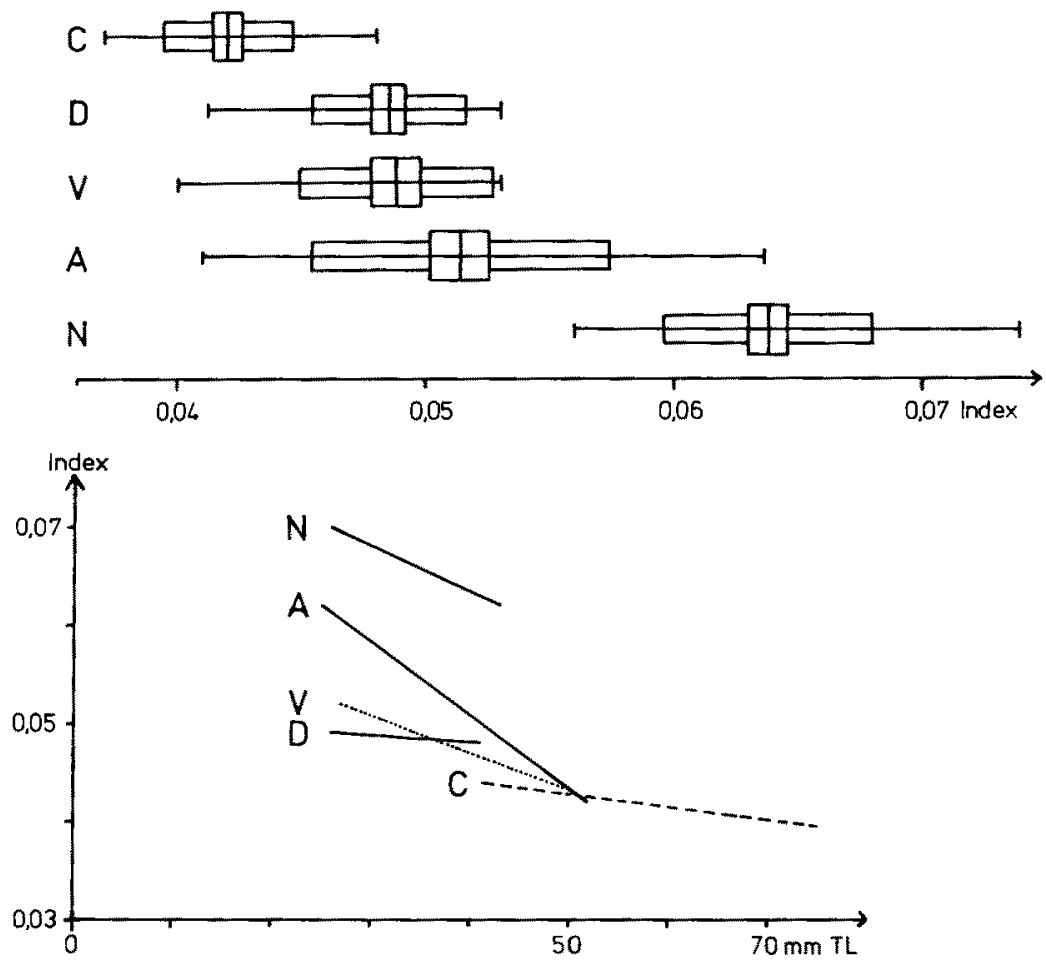

Fig. 13. Miller graph (above) and regression to body length of eye indices of 5 Lipophrys species. (A) L. adriaticus, (C) L. canevai, (D) L. dalmatinus, (N) L. nigriceps, (V) L. velifer

Externally, the eyes of four species investigated more intensively exhibit a crescentmoon-shaped aphacic aperture of the pupil, which seems to be largest in L. nigriceps. Furthermore, the very large lens of this species is conspicuous. The retinae of all 4 species have a coarse surface structure (Fig. 14). In $L$. canevai, $L$. adriaticus and $L$. dalmatinus 1-2 temperodorsal swellings and shallow elevations in the central part are clearly visible. The latter structures form two band-shaped areas in $L$ canevai. In $L$. nigriceps the temperodorsal swelling is only shallow; the retina shows a round depression in the centre in which the lens probably may be retracted (Fig. 14). 

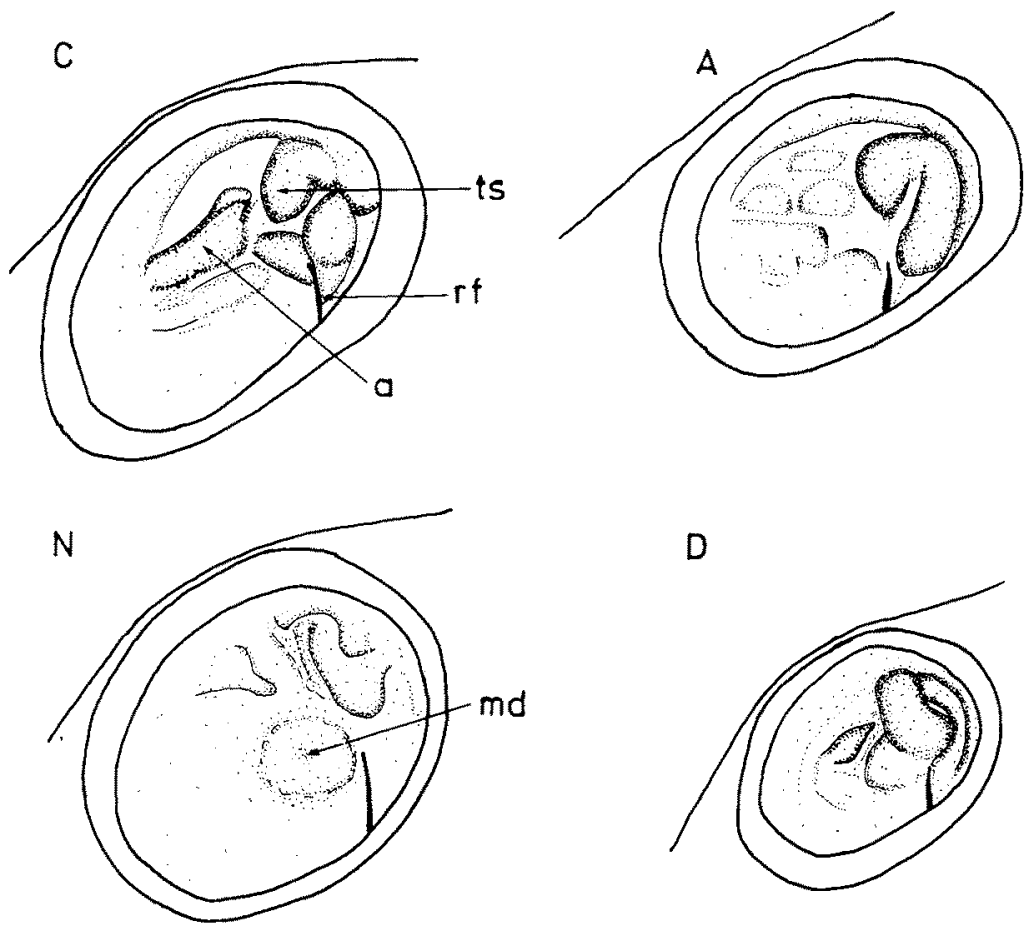

Fig. 14. Structure of retinae of 4 Lipophrys species; a: area, md: medial depression, rf: retinal fissure, ts: temperodorsal swelling (other abbreviations see Fig. 13)

Table 7. Relative lens diameter and number of retinal elements in 4 Lipophrys species

\begin{tabular}{|lcccccccc|}
\hline $\begin{array}{c}\text { Structure or } \\
\text { region of eye }\end{array}$ & $\begin{array}{c}\text { L. canevai } \\
\text { medial }\end{array}$ temporal & $\begin{array}{c}\text { L. adriaticus } \\
\text { medial } \\
\text { temporal }\end{array}$ & $\begin{array}{c}\text { L. dalmatinus } \\
\text { medial }\end{array}$ & $\begin{array}{c}\text { L. nigriceps } \\
\text { temporal } \\
\text { medial temporal }\end{array}$ \\
\hline $\begin{array}{l}\text { Relative lens } \\
\text { diameter }\end{array}$ & 0.428 & - & 0.503 & - & 0.556 & - & 0.607 & - \\
$\begin{array}{l}\text { Upper margin } \\
\text { Receptors }\end{array}$ & $2-3$ & 3 & $1-2$ & 2 & 2 & 2 & $1-2$ & $1-2$ \\
$\quad$ Bipolars & 6 & 7 & 4 & 9 & 5 & 8 & 3 & 5 \\
$\quad$ Ganglion cells & 2 & 3 & 1 & 3 & 2 & 3 & 1 & 2 \\
Area/swelling & 2 & 5 & 2 & 7 & 2 & 6 & 2 & 5 \\
$\quad \begin{array}{l}\text { Receptors } \\
\text { Bipolars }\end{array}$ & 11 & 24 & 12 & 22 & 13 & 24 & 8 & 20 \\
$\quad \begin{array}{l}\text { Ganglion cells } \\
\text { Lower margin }\end{array}$ & 3 & 6 & 3 & 5 & 4 & 5 & 2 & 6 \\
$\quad$ Receptors & 2 & 2 & $1-2$ & 2 & 2 & 2 & $1-2$ & $1-2$ \\
$\quad$ Bipolars & 6 & 6 & 6 & 7 & 6 & 5 & 4 & 5 \\
$\quad$ Ganglion cells & 1 & 1 & 1 & $1-2$ & 1 & 2 & 1 & 1 \\
\hline
\end{tabular}


An examination of histological serial sections provided data on the relative lens diameter (quotient lens diameter to eye diameter). This index is lowest in $L$. canevai and increases in the other species to the highest value in $L$. nigriceps (Table 7). The optic axis of $L$. nigriceps' eye is longer ventrally than in the medial and dorsal part (Fig. 15): ramp retina (Walls, 1967). This might point to a further possibility for accommodation in this species. On the contrary, the other three species show a prolongation of the dorsal axis

c

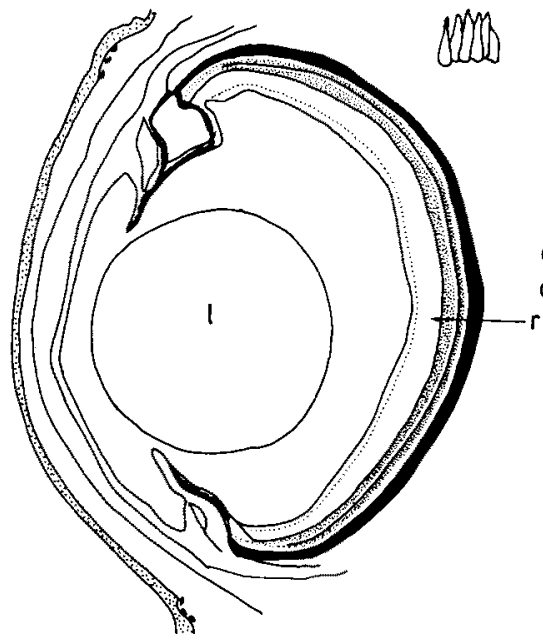

N

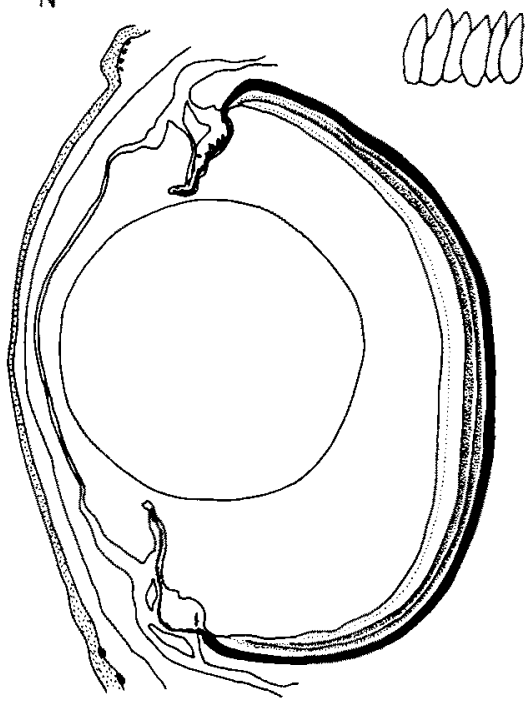

A

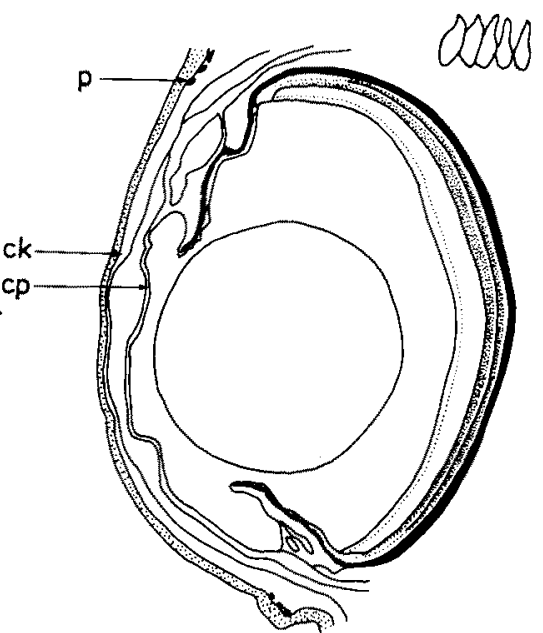

D

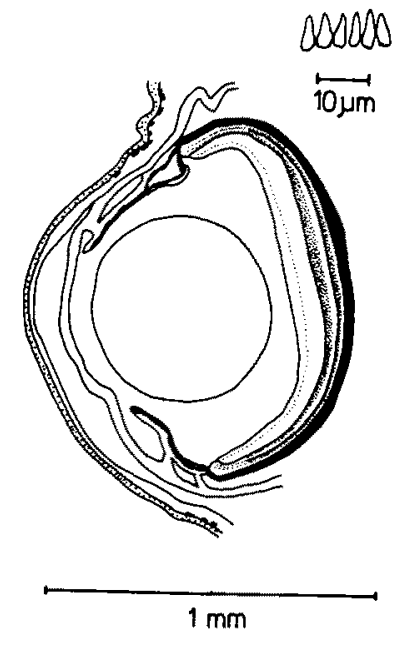

Fig. 15. Schematic cross sections of eyes of 4 Lipophrys species, at upper right: enlarged cones of every retina; ck: cornea conjunctiva, cp: cornea propria, l: lens, p: melanophore, r: retina (other abbreviations see Fig. 13) 
(Fig. 15). The eye pigment reaches far onto the cornea of $L$. canevai, $L$, adriaticus and $L$. dalmatinus, but not in L. nigriceps ( Fig. 15).

The retinae possess more receptors, bipolar and ganglion cells in the temperodorsal swellings than in the central areas or in the marginal retinae (Fig. 15, Table 7). With respect to its shallow area, $L$. nigriceps differs from the other species in having only 8 bipolar and 2 ganglion cells in one row. The ratio of bipolar to ganglion cells is mostly low (except in $L$. adriaticus) and therefore suitable for good resolving power. In this respect $L$. nigriceps has the most advantageous values in the temperodorsal swelling (Table 7).

The number of receptors is also lowest in L. nigriceps (Table 8). The ratio of cones to rods in this species is, with only slight deviations, 1:1. The cones, on the other hand, dominate in the temperodorsal swellings of $L$. adriaticus and $L$. dalmatinus as well as in the area of $L$. canevai, whereas the temperodorsal swelling of $L$. canevai possesses more rods (Table 8). A strikingly high number of receptors is found in the area of $L$. dalmatinus, in contrast to the other species.

The size of the cones varies in the four species: The largest ones are observed in $L$. nigriceps, the smallest in $L$. dalmatinus (Fig. 15). These results correspond only in the latter species to body size, since the cones of $L$. canevai are still smaller than those of $L$. adriaticus. It was not possible to compare the rods in size, as these were covered by pigment in the microscopic sections and only could be recognized by their nuclei.

Table 8 . Ratio of rods to cones in $50 \mu \mathrm{m}$ retina of 4 Lipophrys species

\begin{tabular}{|lcccccc|}
\hline Species & \multicolumn{3}{c}{ Medial } & & & \multicolumn{2}{c|}{$\begin{array}{c}\text { Temporal } \\
\text { margin }\end{array}$} & Area & $\begin{array}{c}\text { Lower } \\
\text { margin }\end{array}$ & $\begin{array}{c}\text { Upper } \\
\text { margin }\end{array}$ & $\begin{array}{c}\text { Swell- } \\
\text { ing }\end{array}$ & $\begin{array}{c}\text { Lower } \\
\text { margin }\end{array}$ \\
\hline L. canevai & $9: 8$ & $10: 13$ & $9: 9$ & $10: 10.5$ & $16.5: 15$ & $6.5: 8$ \\
L. adriaticus & $6.5: 7$ & $13: 13.5$ & $11: 8$ & $7: 6.5$ & $7: 17$ & $10: 8$ \\
L. dalmatinus & $6.5: 9$ & $15: 17.5$ & $9.5: 11$ & $8: 9$ & $1.5 .5: 20$ & $10: 11$ \\
L. nigriceps & $4: 5$ & $11: 11$ & $5: 6.5$ & $7: 7$ & $9: 11$ & $8.5: 7$ \\
\hline
\end{tabular}

\section{DISCUSSION}

The Lipophrys species investigated display not only interspecific differences but also some common patterns. The latter are those factors which may lead to interspecific competition in the case of syntopy. Since $L$. velifer is not distributed in the Mediterranean Sea it will be neglected in this discussion. L. nigriceps, which inhabits dimly lit biotopes, is allotopic with $L$. canevai, $L$. adriaticus and $L$. dalmatinus; therefore the ecological discussion will be concentrated on the latter three species.

\section{Habitat}

The habitats of $L$. canevai and $L$. dalmatinus in the Rovinj area do not differ from sites formerly investigated (Abel, 1962; Zander, 1972b). The classification of $L$. canevai 
as a permanent cave dweller (Riedl, 1966) may be due to it having been confused with "brown" $L$. nigriceps. According to the results obtained the characteristic habitat of $L$. adriaticus lies $0.1-0.5 \mathrm{~m}$ below the water level among steep rocks with little algae coverage. Coast lines which are exposed to heavy surf are probably avoided (klydophoby); concerning sites in the open sea, $L$. adriaticus was only found in sheltered habitats like the entrance channel of the Banjole grotto (Zander \& Jelinek, 1976).

\section{Food}

Although some similarities exist, each of the 3 syntopic species has characteristic feeding habits. The primary reasons lie in the different body sizes of the fish. Hence, meiofauna (especially harpacticoids) plays the greatest part in the diet of L. dalmatinus. Parallel to the decreasing importance of this component for $L$. adriaticus and especially L. canevai, the proportion of algae increases. Gammarids, known to be preyed on by all investigated blenniins, are absent in $L$. adriaticus which had fed on relatively large quantities of anisopods. $L$. adriaticus and $L$. dalmatinus preferred 11 and 10 components of the potentially available food, respectively; $L$. canevai consumed only 4 components, of which algae not only made up the main biomass but also caused a high fullness index. Previous investigations (Gibson, 1968; Zander \& Bartsch, 1972) showed lower proportions of algae in $L$. canevai and $L$. dalmatinus than in the Katarina population. Until now only Parablennius sanguinolentus and $P$. parvicornis, among blenniins, were known to feed exclusively on algae (Gibson, 1968; Zander, 1979b). Though algae made up $75 \%$ of L. adriaticus' food, the species did not prefer this component. Nevertheless, there is a high degree of overlap of ingested food between $L$. canevai and $L$. adriaticus, probably caused by the high algae uptake. Comparing the three species with allotopic Lipophrys, it becomes evident that $L$. nigriceps differs by feeding on $50 \%$ sessile animals and algae, and $L$. trigloides by preying on large quantities of bivalves and gammarids (Zander \& Bartsch, 1972; Zander \& Heymer, 1977).

\section{Morphology}

L. nigriceps possesses 6 small hooks on the inferior rays of the pectoral fins, more than in all other investigated blenniids ( $L$. trigloides has only 5 ; Zander, 1973). Furthermore, $L$. nigriceps differs in the shape of ventral fins, which end obtusely and not acutely as in its relatives. Regarding the narrow body $L$. nigriceps resembles $L$. dalmatinus, whereas $L$. canevai and $L$. adriaticus possess broader heads and bodies. The lateral line is mostly reduced in $L$. dalmatinus and $L$. nigriceps but to a lesser degree in $L$. canevai and $L$. adriaticus.

Having only moderately strong ventral and inferior pectoral fin rays, $L$. adriaticus does not show the adaptations to life in the surf zone that $L$. trigloides does. The degree of reduction of its lateral line also gives evidence of adaptation to calmer areas. Hence, $L$. adriaticus is restricted to sheltered biotopes though living near the water surface. The preferred biotopes of $L$. nigriceps, caves and grottos (Abel, 1962; Zander \& Jelinek, 1976), are at least sheltered in the middle and rear sections (Riedl, 1966). The surprisingly large number of hooks on the pectoral fins may be an adaptation of orientation to the substrate, since L. nigriceps often moves belly-up on the ceilings of caves and therefore must safeguard itself against falling down. 
Only in L. nigriceps could no melanophores of the basic colouring be detected. Their absence, together with the presence of red cells, is responsible for the characteristic cave colouring of the body. The observation of one brown specimen demonstrates that the gene(s) for the basic melanophores have not been lost in this population. Specific melanophore patterns are, on the other hand, permanently visible in this species. It shows a marbled head, strikingly identical with the pattern of Tripterygion melanurus, which also has a red body and is a cave dweller (Zander \& Heymer, 1976, 1977). The mimetic relationship of these two species is underlined by their southern subspecies. $L$. nigriceps portmahonis and T. melanurus melanurus, which have a black tailspot lacking in the northern subspecies, L. nigriceps nigriceps and T. melanurus minor (Zander \& Heymer, 1976, 1977). At spawning time the L. nigriceps $\delta \delta$ possess, like other Lipophrys species, a black and yellow head mask (Abel, 1962; Zander, 1975), whereas Tripterygion melanurus of then differ in that their heads are totally black like other Tripterygion species (Zander \& Heymer, 1976).

The eyes of $L$. nigriceps differ strikingly from those of the other Lipophrys species. They turned out to be the largest in relation to body size and to possess the largest lenses; they show a ventral ramp retina in contrast not only to the other 3 Lipophrys but also to many other fish which have a dorsal one (Munk, 1970). The number of retinal elements is low but the size of the cones exceeds that of other Lipophrys. All these peculiarities can be explained as morphological adaptations to life in caves. The ramp retina is probably an adaptation to the clinging on cave ceilings discussed above. The best accommodation is therefore not possible in the dorsal retina for seeking food but in the ventral part for detecting enemies. This assumption is in agreement with the observation that $L$. nigriceps feeds primarily on aufwuchs and only to a lesser degree on vagile invertebrates. The medial depression in the retina, into which the lens can be withdrawn, is a further accommodation possibility. The retina of this area seems to be fully efficient, contrary to the depression found in the salariin Istiblennius edentulus, where all layers are reduced (Zander, 1974). The other specializations of the eye of $L$. nigriceps are very probably adaptations to the dimly lit biotopes. By the enlargement of the eye and especially the lens a concentration of many light rays onto the retina is possible, thus compensating for the low light intensity in the habitat, which is mostly less than $1 \%$ of the surface light (Zander \& Jelinek, 1976). A further adaptation in this direction is seen on the cornea, where the pigmentation recedes.

Generally, large cones in the retina of fish are an indication for good capabilities of daylight vision (Walls, 1967). In L. nigriceps they may be responsible for the acute shape and colour vision which plays an important role in the social and spawning behaviour. Adaptations to vision at low intensities of light, such as small rods, were not detected directly. On the other hand, the ratio of bipolar to ganglion cells turned out to be very advantageous for high resolving power in L. nigriceps, in spite of the finding that the temporal and medial swellings are very flat in comparison with other Lipophrys species. There may be a direct correlation of the presence of flat swellings, few but large cones and the ratio of bipolar to ganglion cells.

\section{On the evolution of the Lipophrys canevai species group}

Innidiation of species has been considered to be an important evolutionary factor (Ludwig, 1950). It involves the simultaneous adaptation of morphological, physiological 
Table 9. Combination of microhabitat and food overlap of 3 Lipophrys species; range from 0 (no overlap) to 1 (total overlap)

\begin{tabular}{|ccc|}
\hline Species & L. adriaticus & L. dalmatinus \\
\hline L. canevai & 0.571 & 0.398 \\
L. adriaticus & - & 0.367 \\
\hline
\end{tabular}

and ethological characteristics of the population to its ecological niche and to the competitive pressure of other species. The last factor will be greater the more the competitor coincides with the occupier of the niche in morphology and physiology (Remane, 1943). If competitors are lacking, a radiative adaptation to different niches may occur, which leads to very different morphological and physiological characteristics in the following evolutionary processes.

How should we judge the investigated Lipophrys species in this respect? Apparently the species $L$. canevai, $L$. adriaticus, $L$. dalmatinus, and $L$. nigriceps make up a very young group; the close relationship was acknowledged by Zander (1972a) and confirmed by osteological results (Bock, 1979). The two similar species, $L$. pholis and $L$. trigloides, are somewhat less closely related to the group mentioned, whereas $L$. velifer may have a marginal position (Bock, 1979). Therefore it can be assumed that the $L$. canevai species group evolved from a common ancestor which probably was not identical to any of the recent species. This ancestor might have been an inhabitant of the shallow sheltered littoral, since 3 of 4 species are found exclusively in such habitats. It is evident that further speciation led $L$. nigriceps to dimly lit biotopes, and $L$. canevai, by extension of its ecological potential, additionally into surf-exposed biotopes (Zander, $1972 \mathrm{~b}$ ). Only a partial adaptation onto steep rocks by $L$. adriaticus and onto horizontal hard substrates in about $1-m$ depth by $L$. dalmatinus took place. These specializations have gone further in $L$. dalmatinus than in $L$. adriaticus, since the former species is absent among steep rocks (Table 1). In this microhabitat, $L$. adriaticus competes with $L$. canevai, though the latter species generally has its habitat in deeper water and is less abundant.

A specialization regarding individual food components was clearly recognized only in $L$. nigriceps (aufwuchs; Zander \& Heymer, 1977) and, to a lesser degree, in $L$. dalmatinus (meiofauna). Therefore it is understandable that the overlap in the trophic dimensions of the niches occupied is relatively high between $L$. canevai and $L$. adriaticus (Table 5).

A combination of the trophic and microhabitat niche dimensions was made by evaluating the geometrical means of the values given in Tables 2 and 5 . The combined overlap value of $57 \%$ between $L$. canevai and $L$. adriaticus is still very high (Table 9 ). This means, that in spite of many similarities, the syntopy of the 3 species is possible by the existence of, for example, a surplus of prey and a sufficient number of piddock holes for hiding and spawning.

The morphological specializations can be attributed more to the adaptation to distinct microhabitats than to prey. Hence, it is conceivable that only after the microhabitat was chosen did the adaptation to morphology and prey begin. In $L$. nigriceps the morphological specializations are very clearly visible: pigmentation, anatomy of the 
eyes and pectoral fins with 6 hooks for clinging to the ceilings of caves. $L$. canevai possesses only 3 hooks, which are, in contrast, sturdier than in the other 3 species and are suited for clinging to the substrate in the surf zone (Zander, 1973).

The members of the $L$. canevai species group may be considered to be a "Lebensorttyp" (Riedl, 1966; meaning biotope-correlated common structures of a group of related organisms) of the shallow, sheltered rocky littoral. Only L. nigriceps has developed adaptations to life in caves which superimpose on the basic characteristics of this group. Hence, $L$, nigriceps represents the ecological equivalent of the benthic sea cave dweller (Zander \& Heymer, 1977). Since not only regressive (pigmentation) but also progressive evolutionary pathways are present, it is conceivable that predispositions made rapid speciation possible.

Deriving from one "Lebensorttyp", the development of many different morphological and physiological types was possible by (1) adaptation of morphological characteristics to new abiotic factors (e. g. eyes of $L$. nigriceps to low light intensities), and (2) adaptation to biotic factors like exploitation of different food sources (e. g. small body size of $L$. dalmatinus to meiofauna prey).

Acknowledgements. I am indebted to R. Ignacczak and $\mathrm{H}$. Jelinek for help in the field investigations, to Dr. Z. Stevcic and Dr. D. Zavodnik (Institute Ruder Boscovic, Rovinj), to J. Möller-Buchner for examining the phytal samples, A. Dowling for the histological preparations, and to Dr. P. Wirtz for the specimens of Lipophrys velifer. I am grateful also to the Deutsche Forschungsgemeinschaft for a travel grant ( $\mathrm{Za} \mathrm{44/4)}$.

\section{LITERATURE CITED}

Abel, E. F., 1959. Zur Kenntnis der Beziehungen der Fische zu Höhlen im Mittelmeer. - Pubbl. Staz. zool. Napoli 30 (Suppl.), 519-528.

Abel, E. F, 1962. Freiwasserbeobachtungen an Fischen im Golf von Neapel als Beitrag zur Kenntnis ihrer Okologie und ihres Verhaltens. - Int. Revue ges. Hydrobiol. 47, 219-290.

Berg, J., 1979. Discussion of the methods of investigating the food of fishes, with reference to a preliminary study of the food of Gobiusculus flavescens (Gobiidae). - Mar. Biol. 50, 263-273.

Bock, M., 1979. Morphologie der Kopfskelette von Blenniidae (Pisces). Dipl. Arb., Hamburg, 89 pp.

Colwell, R. K. \& Futuyma, D. J., 1971. On the measurement of niche breadth and overlap. - Ecology $52,567-576$.

Gibson, R. N., 1968. The food and feeding relationships of littoral fish in the Banyuls region. - Vie Milieu (A) 19, 447-456.

Hureau, J. C., 1969. Biologie comparée de quelques poissons antarctiques (Nothotheneidae). - Bull. Inst. océanogr. Monaco 68, 1-250.

Ludwig, W., 1950. Zur Theorie der Konkurrenz - Die Annidation (Einnischung) als fünfter Evolutionsfaktor. - Zool. Anz. 145 (Erg.Bd.) 516-537.

Munk, O., 1970. On the occurrence and significance of horizontal band-shaped retinal areae in teleosts. - Vidensk. Meddr dansk naturh. Foren. 113, 85-120.

Remane, A., 1943. Die Bedeutung der Lebensformtypen für die Okologie. - Biol. gen. 17, 164-182.

Riedl, R., 1966. Biologie der Meereshöhlen. Parey, Hamburg, 636 pp.

Walls, G. L., 1967. The vertebrate eye. Hafner, New York, 785 pp.

Zander, C. D., 1969. Mitteilung über die Verbreitung und Okologie von Blennioidei des Mittelmeeres. - Mitt. hamburg. zool. Mus. Inst. 66, 59-63.

Zander, C. D., 1972a. Zur Verbreitungsgeschichte der Gattung Blennius (Blennioidei, Pisces). Mitt. hamburg. zool. Mus. Inst. 68, 213-230. 
Zander, C. D., 1972b. Beiträge zur Okologie und Biologie von Blenniidae (Pisces) des Mittelmeeres. - Helgoländer wiss. Meeresunters. 23, 193-231.

Zander, C. D., 1973. Zur Morphologie der Flossen von Blenniidae (Pisces) des Mittelmeeres. Journées ichthyol. C.I.E.S.M. Rome 1970, 93-96.

Zander, C. D., 1974. Beziehungen zwischen Körperbau und Lebensweise bei Blenniidae (Pisces) aus dem Roten Meer. III. Morphologie des Auges. - Mar. Biol. 28,61-71.

Zander, C. D., 1975. Secondary sex characteristics of Blennioid fishes (Perciformes). - Pubbl. Staz. zool. Napoli 39 (Suppl.) 717-727.

Zander, C. D., 1979a. On the biology and food of small-sized fish from the North and Baltic Sea Area. I. Investigations on Pomatoschistus pictus (Malm) (Gobiidae) from Helgoland. - Zool. Anz. $202,413-424$.

Zander, C. D., 1979b. Morphologische und ökologische Untersuchung der Schleimfische Parablennius sanguinolentus (Pallas, 1811) und $P$. parvicornis (Valenciennes, 1836) (Perciformes, Blenniidae). - Mitt. hamburg. zool. Mus. Inst. 76, 469-474.

Zander, C. D. \& Bartsch, I., 1972. In situ Beziehungen zwischen Nahrungsangebot und aufgenommener Nahrung bei 5 Blennius-Arten (Pisces) des Mittelmeeres. - Mar. Biol. 17, 77-81.

Zander, C. D. \& Heymer, A., 1976. Morphologische und ökologische Untersuchungen an den speleophilen Schleimfischartigen Tripterygion melanurus Guichenot, 1850 und $T$, minor Kolombatovic, 1892 (Perciformes, Blennioidei, Tripterygiidae). - Z. zool. Syst. Evolutionsforsch. $14,41-59$.

Zander, C. D. \& Heymer, A., 1977. Analysis of ecological equivalents among littoral fish. In: Biology of benthic organisms. Ed. by B. F. Keegan, P. O. Ceidigh, \& P. J. S. Boaden. Pergamon Press, Oxford, 621-630.

Zander, C. D. \& Jelinek, H., 1976. Zur demersen Fischfauna im Bereich der Grotte von Banjole (Rovinj/YU) mit Beschreibung von Speleogobius trigloides n. gen. n. sp. (Gobiidae, Perciformes). - Mitt. hamburg. zool. Mus. Inst. 73, 265-280. 